\title{
Regulation of herbal medicines in Brazil: advances and perspectives
}

\author{
Ana Cecília Bezerra Carvalho, ${ }^{1,2,}$, João Paulo Silvério Perfeito ${ }^{1,2}$, Leandro Viana Costa e Silva ${ }^{1,2}$, \\ Lívia Santos Ramalho ${ }^{1,2}$, Robelma France de Oliveira Marquesin, Dâmaris Silveira²
}

${ }^{1}$ Herbal and Homeopathic Medicines Coordenation, National Health Surveillance Agency (ANVISA), ${ }^{2}$ Health Sciences Faculty, University of Brasilia

\begin{abstract}
The National Policy of Integrative and Complementary Practices (PNPIC) in the Brazilian Unified Health System (SUS), and The National Policy of Medicinal Plants and Herbal Medicines (PNPMF) were launched in 2006. Based on these, the Brazilian Health Surveillance Agency (ANVISA) re-edited rules related to herbal medicines such as the Guideline to herbal medicine registration (RDC 14/10), the Good Manufacture Practices Guideline (RDC 17/10) and the List of references to assess the safety and efficacy of herbal medicines (IN 05/10). The requisites to prove herbal medicine's safety and efficacy were updated. Therefore, this review aims at presenting and commenting these new rules.
\end{abstract}

Uniterms: Herbal medicines / Regulation. Herbal medicines / Quality control. Medicines / Good Manufacture Practices. Pharmaceutical industry.

\begin{abstract}
Em 2006, dois importantes documentos foram publicados no Brasil: a Política Nacional de Práticas Integrativas e Complementares (PNPIC) no Sistema Único de Saúde (SUS) e a Política Nacional de Plantas Medicinais e Fitoterápicos (PNPMF) à luz das quais a ANVISA avaliou as normas para o setor. Como produto dessa avaliação, foram republicadas as normas para registro de medicamentos fitoterápicos, por meio da Resolução de Diretoria Colegiada (RDC) 14/10, as Boas Práticas de Fabricação e Controle de medicamentos na indústria farmacêutica, RDC 17/10, e a lista de referências para comprovação da segurança e eficácia de medicamentos fitoterápicos, na forma da Instrução Normativa (IN) 05/10. Em relação às normas anteriormente vigentes, foram atualizados os requisitos para comprovação da segurança e eficácia destes medicamentos e sugeridas alternativas ao controle da qualidade de cada etapa de produção. Dessa forma, essa revisão tem por objetivo apresentar tais normas destacando suas características principais.
\end{abstract}

Unitermos: Medicamento fitoterápico / Regulamentação. Medicamento fitoterápico / Controle de qualidade. Medicamentos / Boas Práticas de Fabricação. Indústria farmacêutica.

\section{INTRODUCTION}

Within the context of the supply chain of medicinal plants and herbal medicines, the Brazilian health legislation, which provides for herbal medicines registration, has recently been updated and published as RDC 14/10, in line with the scientific and technological developments enabling the expansion of the population's access to these medicines (Brasil, 2010b).

\footnotetext{
*Correspondence: Ana Cecília Bezerra Carvalho. Coordenação de Medicamentos Fitoterápicos, Dinamizados e Notificados. Gerência Geral de Medicamentos. Agência Nacional de Vigilância Sanitária. SIA. Trecho 5, Área Especial 57, ${ }^{\circ}$ andar, Bloco B - Brasília-DF. E-mail: anacecijp@yahoo.com.br, damaris@unb.br
}

Herbal Medicine is the technically prepared, industrialized product derived from active raw plant material and it is supposed to feature reproducibility and constancy of quality. Notably, any product that includes natural or synthetic isolated active substances alone, or added to the plant derivative, cannot be classified as a herbal medicine (Brasil, 2010b).

Herbal medicines have always accounted for a significant portion of the medicine market. The industry is worth \$ 21.7 billion per year worldwide and in Brazil alone this market generates \$160 million annually. This amount does not include the relatively broad popular market found mainly within the country. The attraction of this market is the pace of sales growth, over $15 \%$ annually, against $4 \%$ 
obtained from the sale of synthetic drugs. Considering the whole production chain, herbal medicines generate about $\$ 1$ billion annually (FEBRAFARMA, 2007).

In recent decades, efforts in Brazil have been undertaken to stimulate studies of medicinal plants, to promote training of qualified personnel on research, and to introduce herbal alternatives into basic health care (Brasil, 2006b). However, only in 2006 did the Brazilian Government define policies, considered a milestone for the industry of medicinal plants and herbal medicines at the time, in the form of the PNPIC (Ministerial GM/MS 971/06) and PNPMF (Decree 5,813/06). These policies contain among their guidelines, fostering of research on medicinal plants and development of herbal medicines of quality, safety and efficacy standards that must be made available to the population while prioritizing the protection of biodiversity and promoting greater access to safe and effective treatments (Brasil, 2006a,b).

The Brazilian Health Surveillance System, coordinated by ANVISA, is responsible for assessing the herbal medicine industry in Brazil, while State and Municipal assessments are performed by their respective local governments. Therefore, these two policies govern surveillance of marketing, dispensing, handling and distribution of raw materials of plant origin, as well as the registration and supervision of herbal medicine production (Brasil, 1999).

Herbal medicine registration was historically controlled by five specific regulatory rules in Brazil: Ministerial Directives 22 (30 October 1967) (Brasil, 1967), 06 (31 January 1995) (Brasil, 1995), and RDCs 17 (April 23, 2000) (Brasil, 2000), 48 (16 March 2004) (Brasil, 2004a) and 14 (01 April 2010) (Brasil, 2010b).

The legislation taking effect is the newly published RDC 14/10 which differs from its predecessor mainly on the following items: alternative points for quality control of each pharmaceutical production step; registration permit for medicines that contain herbal drugs as their active substance, as long as pre-clinical tests and clinical trials are provided to prove safety and efficacy for the particular pharmaceutical form one wishes to register; requirement of aflatoxin evaluation test, in some cases as suggested by official monographs or the literature; inclusion of multicellular fungi and algae registration whenever a specific regulation has not yet been published (Brasil, 2010b).

It is estimated that there are 512 herbal medicines registered in ANVISA's records derived from approximately 162 medicinal plant extracts and other derivatives (Carvalho et al., 2008a). Despite being a country that is home to $15-20 \%$ of the total number of species on the planet and having a long acceptance of use of medicinal plants among its population (Rodrigues, 2006), only $25 \%$ of the registered herbal medicines in Brazil come from existing medicinal species in South America (Carvalho et al., 2008b). Therefore, it is important that researchers look to health legislation and take a more focused approach on the productive sector in order to generate more information on the Brazilian plant species available, and to ensure more herbal medicines products are registered (Toledo et al., 2003).

\section{HERBAL MEDICINE REGISTRATION IN BRAZIL}

The registration of pharmaceuticals follows parameters so as to demonstrate the quality, effectiveness and safety of the product. The registration dossier consists of a documentary part, a technical report containing data on production and quality control, and a safety and efficacy report.

Herbal medicines can be registered only by pharmaceutical industries previously authorized by ANVISA to manufacture these products. The company must also confirm that it is able to manufacture pharmaceuticals in accordance with the Good Manufacturing Practices and Control protocol (BPFC). In order to achieve this certification, the company must follow internationally standardized norms, internalized in Brazil by the newly published RDC 17/10 (Brasil, 2010a). For herbal medicine production, industries must prove they have employed a qualified pharmacist who will be the technically responsibly officer for the product.

\section{SAFETY AND EFFICACY INFORMATION}

Requirements for proof of safety and efficacy of herbal medicines have not essentially changed since RDC 48/04 (Brasil, 2004a). Companies must submit one of the following alternatives: preclinical and clinical safety and efficacy trials must be carried out, as required to register any other medicine in Brazil; these tests may be exempted if the plant is included in the "list of simplified registration of herbal medicines" (Brasil, 2008b) or if there is sufficient data in the literature validating its safety and efficacy. This validation is a score that can be obtained from a list of standard technical-scientific literature and books, all compiled in IN 05/10 (Brasil, 2010c). The fourth alternative is attesting the traditional use of the product.

IN 05/10 encompasses the "list of bibliographic references for assessment of safety and efficacy of herbal medicines" and presents 35 reference books that are classified in the form of "points". Information on efficacy and safety can also be extracted from monographs and articles on plant species published in indexed journals (Brasil, 2010c). 
The selection of the books was made through assessing technical-scientific references and those selected are divided into three groups (A, B and C), according to the theoretical reference and the monograph model for medicinal plants found in each book. Each reference must inform the herbal derivative used, the plant part this derivative is from, how it is extracted, its recommended posology and therapeutic indication in order to prove its safety and efficacy.

The simplified registration species list, IN 05/08, comprises 36 plant species. Companies must follow all parameters that are specified in the list mentioned, which are: plant organ, chemical standard / marker, plant derivative, therapeutic indications / actions, daily dose, route of administration and restrictions of use. This list was developed considering the various scientific papers published on selected species for simplified registration. Thus, if the plant is present in this list, it is not necessary to submit any additional safety and efficacy data (Brasil, 2008b).

The safety and efficacy data can also be confirmed through the observation of traditional use, ethnopharmacology or ethno-oriented studies and use, technical-scientific documentation, or other publications that show a period equal to 20 years or more of proven efficacy and safety of the product. The proposed period of use for the registered medicinal product, in this case, must be occasional or short (Brasil, 2010c).

The use of medicinal plants, mostly in the form of infusions and decoctions, supports the ethnopharmacological studies, and the companies, when filing for registration of their herbal products, should follow the traditional use patterns as closely as possible. Such caution is necessary to ensure the similarity of the chemical profile of the registered medicinal product to its traditional use.

Only when the product safety and efficacy cannot be accomplished by one of the three mentioned ways above are preclinical and clinical trials required for a specific product. For herbal medicine products, there is a guide to conducting preclinical toxicological trials (RE 90/04) (Brasil, 2004b). This guide sets out the minimum acceptable criteria for conducting acute, sub-chronic and chronic toxicological studies. Additional reproductive toxicity tests and toxicology studies must be conducted for topical products (skin sensitivity; skin and eye irritability). The studies shall be conducted using standardized herbal medicines product samples or the herbal derivatives from which they are originated (Brasil, 2004b).

Once preclinical tests are finalized, clinical studies are necessary to confirm the proposed actions and safety of the drug. In addition to these studies, it is also important to ascertain pharmacokinetic and pharmacodynamic effects and occurrence of possible adverse events. There are Brazilian Health Council norms (CNS) for this purpose: Resolution 196/96 (Brasil, 1996), which regulates any clinical studies conducted in the country, and Resolution 251/97 (Brasil, 1997), specific for drugs and medicines. In order to complement the specific requirements for the registration of medicinal products, ANVISA also published RDC 39 in 2008 as a guide to the conduction of clinical trials (Brasil, 2008a).

Good Clinical Practice guidelines shall be applied to all stages of clinical trials to ensure that the requirements of quality control and ethics are covered (WHO, 2008). ANVISA's guide on Good Clinical Practice determines that, before undergoing any research, the study proposals must be approved by ANVISA then followed by a Special Announcement (CE) issuance (Brasil, 2008a).

The World Health Organization (WHO) guide on clinical research states that the information on the plant species' traditional usage that is going to be clinically tested should be taken into consideration, and, in this case, the chemical composition and form of manufacturing should be similar to the traditional wording used. The parameters related to the quality of the product to be tested must also be observed. In the case of herbal medicines, the guarantee of the identity of the plant species, its standardization and the presence of potential contaminants and adulterations must be observed (OMS, 2008).

Registering medicinal products requires companies to prove, in addition to the safety and efficacy of the product, that they have a pharmacovigilance system that is able to detect adverse effects or harm caused by the use of their products. RDC 04/09 presents guidelines on pharmacovigilance to support the regulated sector (Brasil, 2009a).

\section{QUALITY CONTROL INFORMATION}

It is necessary to conduct various tests in order to demonstrate product's quality. Such tests verify, for example, the identity of plant species and the absence or presence of contaminants within acceptable limits. Control is performed in all production stages: herbal drugs, herbal derivatives, and herbal medicines (Brasil, 2010b).

Contamination of medicinal plants by fungi may give rise to mycotoxins, e.g. aflatoxins, which are carcinogenic (Bugno, 2006). Ways of avoiding this type of contamination include constant monitoring and evaluation of these substances in raw plant materials. There is no specific regulation for aflatoxin limits in herbal medicines in Brazil. The WHO has determined the analysis of aflatoxin types B1, B2, G1, and G2. The presence of any of 
these in raw medicinal plant material is regarded as highly dangerous (Bugno et al., 2006).

Other contaminants that must be observed are: inorganic waste material through ash tests; bacteria and fungi; other plant species, or even parts of the plant species other than the one indicated as a place of greater concentration of actives. The plant species gathering or cropping site and whether methods of eliminating contaminants were used must be informed followed by the search for possible residues.

Identifying a plant species involves sensorial or organoleptic analysis, botanical identification (macroscopic and microscopic analysis), and phytochemical prospecting (Brasil, 2010b).

For herbal derivatives, extraction methods and the detection of solvent residues should be reported. Physicochemical tests are requested including: organoleptic characterization, solid residues, $\mathrm{pH}$, alcoholic content, density (for liquid extracts); moisture loss due to drying, apparent solubility and density (for dry extracts); refractive index, optical rotation (for essential oils); ester, iodine (for fixed oils) and acidity indexes (Brasil, 2010b).

The qualitative and quantitative analysis of markers via chromatographic techniques and spectrometric must be presented. RDC 14/09 lays down specific requisites based on quality assurance, requiring reproducibility of herbal medicines. Marker quantitative control can be replaced by the therapeutic activity's biological control (Brasil, 2010b).

The company that applies for the herbal medicine registration should preferably use the methodologies described in pharmacopeias recognized by ANVISA (RDC 37/2009) for quality control of herbal materials, excipients and herbal medicine (Brasil, 2009d). Otherwise it is necessary to validate the methodologies used. To do so, the method must present the parameters stated by RE 899/03 (Brasil, 2003a); despite having been developed for synthetic drugs, they are also applicable to herbal medicines. Bioanalytical method parameters must be used.

Once the herbal medicine registration is granted, any changes made to the product should be communicated to ANVISA, accompanied by proof of the product's continued quality, safety and efficacy. Companies must follow the procedures specified in the "Guide to making changes and additions to post-registered herbal medicines", RE 91/04 (Brasil, 2004c).

\section{OTHER APPLICABLE REGULATIONS}

Other regulations can be applied to herbal medicines, including: restriction of sale criteria, i.e. whether or not the medicinal product will be sold as a prescription medicine (Brasil, 2003b); a stability study guide (Brasil, 2005a), good manufacturing practices, quality control and storage outsourcing (Brasil, 2007), medicinal products advertising norms (BRASIL, 2008c), standardization of package leaflet (Brasil, 2009b), packaging models and wordings (Brasil, 2009c), and good manufacturing practices for raw material (Brasil, 2005b).

RDC 138/03 sets down the medicinal products that do not require prescription prior to sale, except for parenterally administered products. All therapeutic indications that are not described in this list are sold under prescription (Brasil, 2003b).

RE 01/05 provides for the information that must be present in all stability study reports for each pharmaceutical form, and also covers stability study monitoring and photostability. The stability study of medicines should be carried out in both accelerated mode as well as long lasting mode. The accelerated study is designed to accelerate the chemical degradation and / or physical changes of a pharmaceutical product in forced storage conditions. The long-term study is designed for the verification of physical, chemical, biological, and microbiological characteristics of a pharmaceutical product during (and optionally after) the expected expiry date. The results are used for the establishment or confirmation of the product's expiry date and recommendations for the appropriate storage conditions for the product at the marketing point and by the user (Brasil, 2005b).

RDC 47/09 lays down rules for patients and health professionals concerning leaflets. In parallel, package leaflets for herbal medicines have been standardized. There are leaflets standardized for 18 plant species in order to ensure that standardized product information is available to the population (Brasil, 2009c).

RDC 71/09 states medicine labeling parameters. It was published in order to improve the form and content of the labels of all registered medicinal products marketed in Brazil. It also introduced the obligation of manufacturing labels to appear in Braille (Brasil, 2009b).

Labels must contain alerts on after-preparation conservation of the medicinal products and inform that its expiry date is reduced once the package is open. The inclusion of identification and security mechanisms to enable tracking of the product from manufacturing to dispensing are also included in the labels (Brasil, 2009d).

\section{CONCLUSION}

Adjustments to the entire production chain of herbal medicines offer safe, efficacious quality products to the 
population, avoiding health problems, such as poisoning, aggravation of diseases, and therapeutic failures.

This updating of the standard herbal medicine registration caters to the needs of PNPMF, PNPIC, and introduces alternatives for herbal medicine quality control. Despite boasting one of the world's greatest biodiversity and being one of the countries that publishes the largest number of scientific articles on medicinal plants and herbal medicines, Brazil still has an unimpressive number of herbal medicines registered containing Brazilian plant species. Thus, knowledge of the regulatory surveillance health system, participation in the establishment of regulation standards, whether through direct action of ANVISA or through contributions from public consultations, and performance of tests in accordance to the prevailing norms are essential for the positive development of the sector's regulation system, providing a scientific character to the legislation. Studies concerning regulatory requirements, so that they can be leveraged in the registration of medicines and in improving herbal medicines registration process, can contribute to the introduction of safe, efficacious, and good quality products in the market.

\section{REFERENCES}

BRASIL. Congresso Nacional. Portaria no. 22, de 30 de outubro de 1967. Estabelece normas para o emprego de preparações fitoterápicas. Diário Oficial da União. Brasília, 16 nov. 1967. Seção 1, p.45-46.

BRASIL. Ministério da Saúde. Secretaria de Vigilância Sanitária. Portaria no. 06, de 31 de janeiro de 1995. Institui e normatiza o regulamento e produtos fitoterápicos junto à Secretaria de Vigilância Sanitária. Diário Oficial da União. Brasília, 06 fev. 1995. Seção 1, p.23.

BRASIL. Ministério da Saúde. Conselho Nacional de Saúde. Resolução no. 196, de 10 de outubro de 1996. Aprova as diretrizes e normas regulamentadoras de pesquisa envolvendo seres humanos. Diário Oficial da União. Brasília, 16 out. 1996. Seção1, p. 83.

BRASIL. Ministério da Saúde. Conselho Nacional de Saúde. Resolução no. 251, de 07 de agosto de 1997. Aprova normas de pesquisa envolvendo seres humanos para a área temática de pesquisa com novos fármacos, medicamentos, vacinas e testes diagnósticos. Diário Oficial da União. Brasília, 23 set. 1997. Seção 1, p. 33-35.
BRASIL. Congresso Nacional. Lei no. 9782, de 26 de janeiro de 1999. Define o Sistema nacional de vigilância sanitária, cria a Agência nacional de vigilância sanitária, e dá outras providências. Diário Oficial da União. Brasília, 27 jan. 1999. Seção 1, p. 21-26.

BRASIL. Ministério da Saúde. Agência Nacional de Vigilância Sanitária. RDC no. 17, de 24 de fevereiro de 2000. Aprova o regulamento técnico de medicamentos fitoterápico junto ao Sistema de Vigilância Sanitária. Diário Oficial da União. Brasília, 25 fev. 2000. Seção 1, p.25-26.

BRASIL. Ministério da Saúde. Agência Nacional de Vigilância Sanitária. RE no. 899, de 29 de maio de 2003. Determina a publicação do "Guia para validação de métodos analíticos e bioanalíticos". Diário Oficial da União. Brasília, 02 jun. 2003a. Seção 1, p. 56-59.

BRASIL. Ministério da Saúde. Agência Nacional de Vigilância Sanitária. RDC no. 138, de 29 de maio de 2003. Dispõe sobre o enquadramento na categoria de venda de medicamentos. Diário Oficial da União. Brasília, 02 jun. 2003b. Seção 1, p.32.

BRASIL. Ministério da Saúde. Agência Nacional de Vigilância Sanitária. RDC no. 48, de 16 de março de 2004. Aprova o regulamento técnico de medicamentos fitoterápico junto ao Sistema Nacional de Vigilância Sanitária. Diário Oficial da União. Brasília, 18 mar. 2004a. Seção 1, p.39-41.

BRASIL. Ministério da Saúde. Agência Nacional de Vigilância Sanitária. RE no. 90, de 16 de março de 2004. Dispõe sobre o "Guia para os estudos de toxicidade de medicamentos fitoterápicos”. Diário Oficial da União. Brasília, 18 mar. 2004b. Seção 1, p.34-35.

BRASIL. Ministério da Saúde. Agência Nacional de Vigilância Sanitária. RE no. 91, de 16 de março de 2004. Dispõe sobre o "Guia para realização de alterações, inclusões, notificações e cancelamento pós-registro de fitoterápicos". Diário Oficial da União. Brasília, 18 mar. 2004c. Seção 1, p.35-37.

BRASIL. Ministério da Saúde. Agência Nacional de Vigilância Sanitária. RE no. 01, de 29 de julho de 2005. Autoriza ad referendum, a publicação do Guia para a realização de estudos de estabilidade. Diário Oficial da União. Brasília, 01 ago. 2005a. Seção 1, Suplemento, p.1-2. 
BRASIL. Ministério da Saúde. Agência Nacional de Vigilância Sanitária. RDC no. 249, de 13 de setembro de 2005. Determina a todos os estabelecimentos fabricantes de produtos intermediários e de insumos farmacêuticos ativos o cumprimento das diretrizes estabelecidas no Regulamento técnico das Boas Práticas de Fabricação de produtos intermediários e insumos farmacêuticos ativos. Diário Oficial da União. Brasília, 26 set. 2005b. Seção 1, Suplemento, p.1-11.

BRASIL. Presidência da República. Decreto no. 5813, de 22 de junho de 2006. Aprova a Política Nacional de Plantas Medicinais e Fitoterápicos e dá outras providências. Diário Oficial da União. Brasília, 23 jun. 2006a. Seção 1, p.2-4.

BRASIL. Ministério da Saúde. Portaria no. 971, de 03 de maio de 2006. Aprova a Política Nacional de Práticas Integrativas e Complementares (PNPIC) no Sistema Único de Saúde. Diário Oficial da União. Brasília, 04 mai. 2006b. Seção 1, p.20-25.

BRASIL. Ministério da Saúde. Agência Nacional de Vigilância Sanitária. RDC no. 25, de 29 de março de 2007. Dispõe sobre a terceirização de etapas de produção, de análise de controle de qualidade e de armazenamento de medicamentos. Diário Oficial da União. Brasília, 02 abr. 2007. Seção 1, p.56-57.

BRASIL. Ministério da Saúde. Agência Nacional de Vigilância Sanitária. RDC no. 39, de 05 de junho de 2008. Aprova o regulamento para a realização de pesquisa clínica e dá outras providências. Diário Oficial da União. Brasília, 01 ago. 2008a. Seção 1, p.75-80.

BRASIL. Ministério da Saúde. Agência Nacional de Vigilância Sanitária. IN no. 05, de 11 dezembro 2008. Determina a publicação da "Lista de medicamentos fitoterápicos de registro simplificado". Diário Oficial da União. Brasília, 12 dez. 2008b. Seção 1, p. 56-58.

BRASIL. Ministério da Saúde. Agência Nacional de Vigilância Sanitária. RDC no. 04, de 10 de fevereiro de 2009. Dispõe sobre as normas de farmacovigilância para os detentores de registro de medicamentos de uso humano. Diário Oficial da União. Brasília, 11 fev. 2009a. Seção 1, p.42-43.

BRASIL. Ministério da Saúde. Agência Nacional de Vigilância Sanitária. RDC no. 23, de 20 de maio de 2009. Dispõe sobre a propaganda, publicidade, informação e outras práticas cujo objetivo seja a divulgação ou promoção comercial de medicamentos. Diário Oficial da União. Brasília, 21 mai. 2009b. Seção 1, p.53-54.
BRASIL. Ministério da Saúde. Agência Nacional de Vigilância Sanitária. RDC no. 47, de 8 de setembro de 2009. Estabelece regras para elaboração, harmonização, atualização, publicação e disponibilização de bulas de medicamentos para pacientes e para profissionais de saúde. Diário Oficial da União. Brasília, 09 set. 2009c. Seção 1. p.31-36.

BRASIL. Ministério da Saúde. Agência Nacional de Vigilância Sanitária. RDC no. 71, de 22 de dezembro de 2009. Estabelece regras para a rotulagem de medicamentos. Diário Oficial da União. Brasília, 23 dez. 2009d. Seção 1, p.75-80.

BRASIL. Ministério da Saúde. Agência Nacional de Vigilância Sanitária. RDC no. 37, de 06 de julho de 2009. Trata da admissibilidade de Farmacopéias internacionais. Diário Oficial da União. Brasília, 08 jul. 2009e. Seção 1, p.40.

BRASIL. Ministério da Saúde. Agência Nacional de Vigilância Sanitária. RDC no. 17, de 16 de abril de 2010. Dispõe sobre as boas práticas de fabricação de medicamentos. Diário Oficial da União. Brasília, 19 abr. 2010a. Seção 1, p.94-110.

BRASIL. Ministério da Saúde. Agência Nacional de Vigilância Sanitária. RDC no. 14, de 30 de março de 2010. Dispõe sobre o registro de medicamentos fitoterápicos. Diário Oficial da União. Brasília, 5 abr. 2010b. Seção 1, p.85-87.

BRASIL. Ministério da Saúde, Agência Nacional de Vigilância Sanitária. IN no. 05, de 31 de março de 2010. Lista de referências bibliográficas para avaliação de segurança e eficácia de medicamentos fitoterápicos. Diário Oficial da União. Brasília, 5 abr. 2010c. Seção 1, p.91.

BUGNO, A. Drogas vegetais: avaliação da contaminação microbiana e pesquisa de aflatoxinas, ocratoxina A e citrinina. São Paulo, 2006. 219 p. [PhD Thesis. Faculdade de Ciências Farmacêuticas, Universidade de São Paulo].

Bugno, A., Almodovar, A. A. B., PEREIRA, T. C., PINTO, T. J. A. and SABINO, M. Occurrence of toxigenic fungi in herbal drugs. Braz. J. Microbiol, v.37, n.1, p.4751.2006

CARVAlHO, A. C. B., BALBINO, E. E., MACIEL, A. and PERFEITO, J. P. S. Situação do registro de medicamentos fitoterápicos no Brasil. Rev. Bras. Farmacogn., v.18, n.2, p.314-319. 2008a. 
CARVALHO, A. C. B.; SANTOS, L. A.; SILVEIRA, D. La regulación de los medicamentos herbarios en Brasil. Bol. Latinoam. Caribe Plantas Med. Aromat., v.8, n.1, p.7-11. 2008 b.

FEBRAFARMA. Federação Brasileira da Indústria Farmacêutica. Fitoterápico atrai investimentos; 2007 [Citado: 2007 ago. 22] Disponível em: http://www. febrafarma.org.br/areas.php?area $=$ pu\&secao $=38 \&$ modul $\mathrm{o}=$ materias

ORGANIZAÇÃO MUNDIAL DA SAÚDE. OMS. Instruções operacionais: informações necessárias para a condução de ensaios clínicos com fitoterápicos. Brasília: Ministério da Saúde. 2008. 20 p.
RODRIGUES, A. G. Fitoterapia no Sistema Único de Saúde. In: Anais da V Jornada Catarinense e I Jornada Internacional de Plantas Medicinais, Joinville: Ed. Univille. 2006. p.68-69.

TOLEDO, A. C. O., HIRATA, L. L., MARILENE DA CRUZ, M. B., MIGUEL, M. D. and MIGUEL, O. G. Fitoterápicos: uma abordagem farmacotécnica. Revista Lecta, v.21, n.1/2, p.7-13. 2003.

Received for publication on $30^{\text {th }}$ December 2010 Accepted for publication on $11^{\text {th }}$ May 2011 
